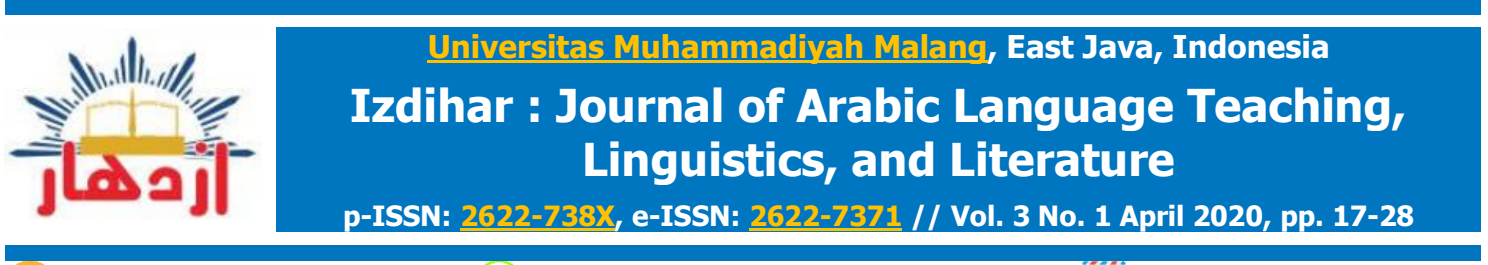

doi

https://doi.org/10.22219/jiz.v3i1.11033

izdihar.jurnalpba@umm.ac.id

\title{
Improving Quality of Arabic Translation Course through Jigsaw Cooperative Learning
}

\author{
Tika Fitriyaha, 1 , Moh. Fery Fauzib, 2 \\ aUIN Sunan Kalijaga Yogyakarta, Indonesia \\ bUniversitas Muhammadiyah Malang, Indonesia \\ 1tika.fitriyah@uin-suka.ac.id, ${ }^{2}$ mohferyfauzi@umm.ac.id*
}

\section{ARTICLE INFO}

Article History:

Received: $21 / 01 / 2020$

Revised: $29 / 04 / 2020$

Accepted: $29 / 04 / 2020$

Published: $30 / 04 / 2020$

\section{*Corresponding}

\section{Author:}

Name: Moh. Fery

Fauzi

Email:

mohferyfauzi@umm.ac.id

\section{ABSTRACT}

Translation is not only a process of language transfer, but also a transfer of culture from the source language to the target language. For this reason, translators must have broad and rich insights. The process to enrich cultural insights, knowledge, and treasures in the translation process can be formed through Jigsaw Cooperative Learning model because it is student-centered learning and requires them to independently seek and share knowledge. This study aimed to improve the ethos of students learning in Arabic translation subject and to improve students' Arabic translation quality. This classroom action research was conducted two cycles (repeated seven times). Each cycle referred to Spiral Model by Kemmis, McTaggart, and Nixon. The subjects were 52 students of C Class and D Class in Terjemah Arab-Indonesia Course at Arabic Language and Literature Department of UIN Sunan Kalijaga Yogyakarta. The data of students' learning ethos were obtained from performance grading rubric in Jigsaw Cooperative Learning and the data of Arabic translation quality were obtained from students worksheet assesment and end-of-cycle Arabic translation test. The results showed that Jigsaw Cooperative Learning improved (1) the learning ethos, especially the independence of students in seeking and sharing knowledge through Jigsaw Cooperative Learning and (2) the quality of Arabic-Indonesia translation. This model was effectively used for this course because students can translate longer texts with relatively short time.

Copyright (c) 2020, Fitriyah et al This is an open access article under the CC-BY-SA license

Arabic Translation; Jigsaw; Terjemah Arab-Indonesia Course; Translation Quality

\section{مستخلص البحث}

الترجمة ليست فقط عملية نقل اللغة ، ولكن أيضًا نقل الثقافة من لغة المصددر إلى اللغة الهدف. لهذا السبب ، يجب أن يكون المترجمون رؤى واسعة

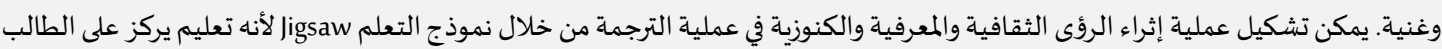

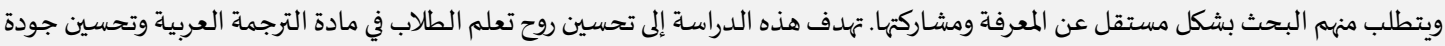

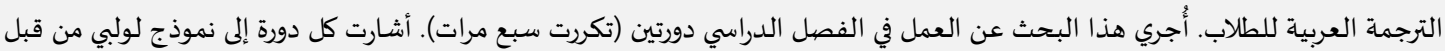

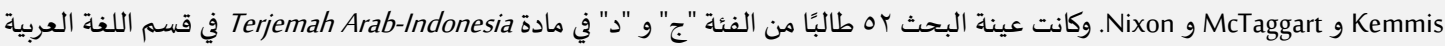

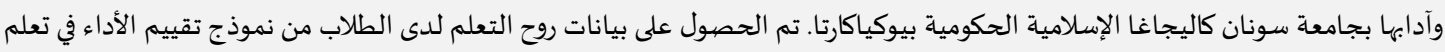

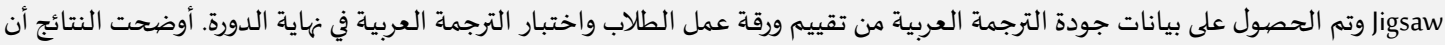
ligsaw

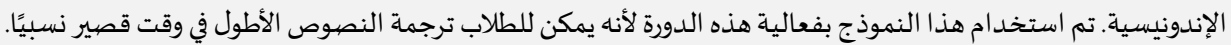

$$
\text { كلمات أسـاسية الترجمة العربية ؛ Jigsaw؛ مادة الترجمة العربية - الإندونيسية؛ جودة الترجمة }
$$

Please cite this article as Fitriyah, T., Fauzi, M. F. (2020). Improving Quality of Arabic Translation Course through Jigsaw Cooperative Learning. Izdihar : Journal of Arabic Language Teaching, Linguistics, and Literature, 3(1), 17-30. DOI: https://doi.org/10.22219/jiz.v3i1.11033 


\section{INTRODUCTION}

One of the basic requirements to be a translator is language acquisition. This is an absolute requirement to be a translator that cannot be replaced, although at the moment there are many language dictionaries and translator machine that can help translators in the translation process. Pellicer-Sánchez, (2016) said that basically, mastering the language does not mean knowing only vocabulary, even it is one of essential things for fluent second language (L2), but all things that are at the level of language. So that the transfer of meaning in accordance with the desired context of the text.

The role of translation is important until the Arabic-Indonesian translation became a subject course that must be studied by all students of Arabic Language and Literature Department, especially in the Arabic Language and Literature Department of UIN Sunan Kalijaga Yogyakarta. This course has 4 credits so that in one semester there are 30 meetings. Generally, this course aims to produce reliable translators.

Background of diverse student abilities and relatively short time become a fact that it is not an easy thing for students to achieve these abilities. Many students are also able to receive messages for themselves but fail to convey to others because of their weak translation skills (Hidayatullah, 2017), but many students have difficulty in understanding Arabic texts. Instead of text, students are only able to translate one or two paragraphs for each meeting because students have different abilities with limited time to be able to complete the translated text (Sari, 2018). Students need a framework that prioritizes field meaning (Asrori, 2016), meaning relation (Nikmah, 2019), function over structure and correctness (Caplan, 2019), and human culture (Mahbubah, Biahmada, \& Mauludiyah, 2020).

Researchers found problems in teaching Terjemah Arab-Indonesia course. Based on researchers' observations in this course, students need relatively long time to translate Arabic texts. At the first meeting in class of second year students of Arabic language and literature department of UIN Sunan Kalijaga Yogyakarta in August 2019, the researcher gave 2 paragraphs of Arabic text to be translated into Indonesian. From 52 students of $C$ and D class, there are about 45 students who need nearly 60 minutes to translate 2 paragraphs. The activity was carried out again at the second meeting using a different Arabict text. The result was almost the same as the first meeting. In addition, students did not interact much with other students in translating Arabic texts. Whereas students need to conduct discussions, collaborations, and exchange ideas until they have the right perspective and perception in translating Arabic texts because translation does not only translate words and meanings but also culture and context of meaning. 
In some references, translation is adopted as an alternative way to learn Arabic. Nurbayan (2014) conducted research on the influence of Arabic structure on Indonesian in Al-Qur'an translation. Baharudin (2017) conducted investigating study on translation strategy and technic of Arabic novel used by students of higher education in Malaysia. Ariyanti and Tanjung (2019) conducted study on relation between translator competence and translation quality. Habibullah (2015) also conducted a case study on translation process and result of students in higher education. Perdana (2017) conducted only a library research on acceptable and understandable Arabic translation strategy. All of the abovementioned previous studies have not been able to make students actively and collaboratively learn Terjemah Arab-Indonesia Course.

There have been various methods applied in learning Arabic-Indonesian translation course but it is still not successful. Whereas recent educational standard designed to ensure and develop students' academic language skill (Barr, Uccelli, \& Galloway, 2019). The researchers have directly used the method of qawa'id wa tarjamah but it does not make students actively translate text. In addition, this method requires a long time. Other methods and strategies were also conducted. Researchers have applied the direct method, problem-based learning method, discovery method, teams games tournament (TGT) strategy (Fauzi, Buhun, \& Purwadi, 2019) and so on, but these methods are not suitable for translation learning course and require a long time in translating long texts. The translation error is also a serious mistake (Harahap, 2014). Therefore, an appropriate method is needed so that the targeted competencies can be achieved because language transfer needs at least competence in linguistics, psychology, and pedagogy (Wicaksono \& Roza, 2015).

Jigsaw Cooperative Learning is one of active learning methods that guides student activity. With this method, all students can independently search for knowledge and share knowledge with classmates. Jigsaw Cooperative Learning method helps students learn or translate large amounts of text in a relatively short amount of time, because the general description of this method is to work on texts in mutual cooperation. Jigsaw Cooperative Learning can improve cognitive abilities such as analysis, synthesis, and evaluation. In addition, this method can also increase the ability of affection, namely assessment, attitude determination, value organization and even to the formation of lifestyle.

As far as the researchers know, there was no previous research that has investigated Jigsaw Cooperative Learning applied to translation learning course. Based on this gap, this research has its own appeal that it can contribute to the learning of Arabic-Indonesia translation course, both in the Arabic Language and Literature department and in other majors who study this course. Somadayo (2013) suggested classroom action research to improve teaching and learning 
quality. So, this research implemented Jigsaw Cooperative Learning by implementing classroom action research.

This study aimed to improve the learning ethos, especially the independence of students in seeking and sharing knowledge through Jigsaw Cooperative Learning. It also aimed to improve students' Arabic translation quality because there are many competencies that can be generated from this cooperative learning.

After studying various previous studies related to this research, the position of this research in the academic realm is an offer or a new breakthrough in teaching Arabic-Indonesia translation course by using Jigsaw Cooperative Learning method. In other words, the researchers have collaborated the translation of learning as a material object with the Jigsaw Cooperative Learning method as a formal object to find out how the method works and the extent to which the method influences learning in translation.

\section{METHOD}

The type of research was Classroom Action Research (CAR). The subjects were 52 students of C Class and D Class in Terjemah Arab-Indonesia Course at Arabic Language and Literature Department of UIN Sunan Kalijaga Yogyakarta. The students were in odd semester of the academic year 2019-2020. The study was conducted from August until October 2019.

This research was categorized as participation CAR because the researcher was a lecturer who was directly involved in the research process from the beginning to the end of the report preparation. The researcher was participant researcher that taught directly Terjemah Arab-Indonesia course in C and D class in Arabic language and literature department.

The study was conducted in 14 meetings and in 2 cycles of CAR. The cycle ended when the percentage of students graduation in Terjemah Arab-Indonesia course was above $90 \%$. The minimum graduation standard of this course was when the students achieved score minimally 55 (grade $\mathrm{C}$ ) based on score standard in UIN Sunan Kalijaga Yogyakarta.

The first cycle studied basic translation such as definition, translator, term, urgency of translation, and basic translation exercises. The second cycle studied one anthology of poetry entitled "Kitab al-Hubb" written by Nizar Qabbani (1970). Each cycle consisted of seven meetings. The CAR had four main stages in each cycle: (1) planning; (2) implementation; (3) observation; and (4) reflection referring to Spiral Model by Kemmis, McTaggart, and Nixon (2014).

The data were analyzed qualitatively. Descriptive-qualitative method of data analysis was adopted from Miles, Huberman, and Saldana (2014) that 
includes: (1) reduction of data; (2) systematic and logical descriptive presentation; (3) making conclusions based on the presented results; and (4) verification. The data of students' learning ethos were obtained from questionnaire for measurement matrix of learning ethical index in Jigsaw Cooperative Learning and the data of Arabic translation quality were obtained from students worksheet assesment and end-of-cycle Arabic translation test.

Data analysis was carried out from the activities in the beginning until the end of CAR. The data resulted from the activites were processed and analyzed qualitatively. This study also used comparative descriptive technique for quantitative data. It was conducted by comparing the results and data of each cycle in the form of students scores table.

This research had two cycles and four steps in each cycle. First step, the researchers made a planning that consisted of: (1) designing the syllabus; (2) preparing the learning implementation plan with Jigsaw Cooperative Learning; (3) preparing phenomena in the form of pictures, videos, or experiments; (4) creating student worksheet; (5) creating an observation sheet for the implementation of Jigsaw Cooperative Learning; (6) designing a rubric to measure the ethos of students learning and quality of Arabic translation; (7) designing indicators and rubric score.

The second and the third step consisted of two main activities, implementation and observation. Jigsaw Cooperative Learning was implemented in the two classrooms. The observation consisted of (1) preliminary and opening activities in accordance with the phenomena in everyday life, students' knowledge, and explanation of learning objectives; (2) the main activities of Jigsaw Cooperative Learning in Terjemah Arab-Indonesia Course; (3) review, conclussion, and closing the meeting. The fourth step was reflection. Lecturer and observers provided input from results of analysis and discussion that were used to improve the implementation of the learning process in the next cycle. The data resulted in first cycle was used for the next cycle to make improvements.

\section{RESULTS \& DISCUSSION}

\section{Improving Students' Learning Independence}

Based on the data of research, the results of this study indicated that the Jigsaw Cooperative Learning method is able to improve the ethos of learning while improving the quality of student translation results. It is evidenced by an increase in the ethos of learning during the learning process and a significant increase in outputs after students receive learning using the Jigsaw Cooperative Learning method. The implementation of the Jigsaw Cooperative Learning method in this translation course was carried out in two stages of the cycle. 
Tabel 1. Measurement Matrix of Learning Ethos Index

\begin{tabular}{|c|c|c|c|c|}
\hline No. & Indicator & Indicator Items & $\begin{array}{c}\text { Scoring } \\
\text { Scale }\end{array}$ & $\begin{array}{c}\text { Percentage } \\
\text { Score }\end{array}$ \\
\hline 1 & $\begin{array}{l}\text { Interest in } \\
\text { reading }\end{array}$ & $\begin{array}{l}\text { - } \text { Allocation of reading time per } \\
\text { - } \text { day } \\
\text { - } \text { Frequency of visiting the library } \\
\text { - } \quad \text { Attitudes towards reading } \\
\text { activities }\end{array}$ & $1-5$ & $21.0 \%$ \\
\hline 2 & Responsibility & $\begin{array}{l}\text { - Commitment of time to complete } \\
\text { the task } \\
\text { - Commitment of time to } \\
\text { understanding new knowledge } \\
\text { - Completeness of work on } \\
\text { assignments }\end{array}$ & $1-5$ & $25.0 \%$ \\
\hline 3 & $\begin{array}{l}\text { Learning } \\
\text { Independence }\end{array}$ & $\begin{array}{l}\text { - } \text { Ability to set a learning agenda } \\
\text { and lessons } \\
\text { - } \text { Belief in self abilities } \\
\text { - } \quad \text { Do not depend on others }\end{array}$ & $1-5$ & $42.5 \%$ \\
\hline 4 & $\begin{array}{l}\text { Courage to } \\
\text { Face } \\
\text { Challenges }\end{array}$ & $\begin{array}{l}\text { - } \text { Enthusiasm for work } \\
\text { - Interest in high risk } \\
\text { - Interest in competence } \\
\text { - High curiosity } \\
\text { - } \quad \text { Courage to ask highly }\end{array}$ & $1-5$ & $11.5 \%$ \\
\hline
\end{tabular}

Tabel 1 is about measurement matrix of learning ethos index by Hunt (Wahyono, Hardiant, \& Miyarso, 2014). The researchers used that measurement matrix to find the data of students' learning ethos by using questionnaire for conducting Jigsaw Cooperative Learning. The matrix has 15 indicator items that has been classified into 4 indicators. The 4 indicators were compared to know the highest impact of Jigsaw Cooperative Learning on students' learning ethos. The four indicators are: 1 ) interest in reading that reached $21 \%$; 2) students' responsibility that reached $25 \% ; 3$ ) learning independence that reached $42,5 \%$; and courage to face challenges that reached $11,5 \%$. From 4 indicators, Jigsaw Cooperative Learning has big impact to students' learning independence. Through Jigsaw Cooperative Learning, students have ability to set a learning agenda and lessons. Jigsaw Cooperative Learning improved belief in self abilities for students. It also made students not to depend on others complete the tasks and responsibilities. It is in line with the statement from Yamada, Goda, Hata, Matsukawa, and Yasunami (2016) that the Jigsaw collaborative learning approach can be one of effective instructional approach for the enhanchment of learning responsibilities and interaction.

Before the Jigsaw Cooperative Learning method was used in translation courses, observational data showed that as many as $67.30 \%$ of all students had 
a low learning ethos, $21.15 \%$ had a moderate learning ethos, and only $11.53 \%$ had a high learning ethos. Meanwhile, the ethos of student learning showed improvement after the use of the Jigsaw Cooperative Learning method, with the following percentages: $17.30 \%$ of students had a low learning ethic, $28.84 \%$ had a moderate learning ethic, and $53.84 \%$ had a high learning ethos. The percentage of learning ethos used in this study adapted Hunt's theory (Wahyono et al, 2014) with the index measurement matrix as in Tabel 1 . This learning ethos also develops students' learning indpendence because through Jigsaw Cooperative Learning, students actively seek knowledge and vocabulary from reading, listening, and viewing (Feng \& Webb, 2019). Learning process will be easy when students actively seek knowledge themselves (Fahrurrozi, 2014).

\section{Improving Students' Arabic-Indonesian Translation Quality}

The researchers in this study applied Jigsaw Cooperative Learning in Terjemah Arabic-Indonesia Course after conducting a pretest. This method is a pedagogical practice that provides learners with cognitive, affective, and psychomotor attainments (Karacop \& Diken, 2017). The advantage of this method is that translation activities are carried out in groups so that students are more enthusiastic in the process before they are ready to translate individually.

Before implementing Jigsaw Cooperative Learning, the researchers conducted pretest. This pretest aimed to know students' translation skill in Terjemah Arab-Indo course. Students were given an Arabic text to be translated into Indonesian. This activity was repeated after implementing Jigsaw Cooperative Learning as posttest.

\section{Graphic of Score Improvement for Terjemah Arab- Indonesia Course in Cycle 1 and Cycle 2}

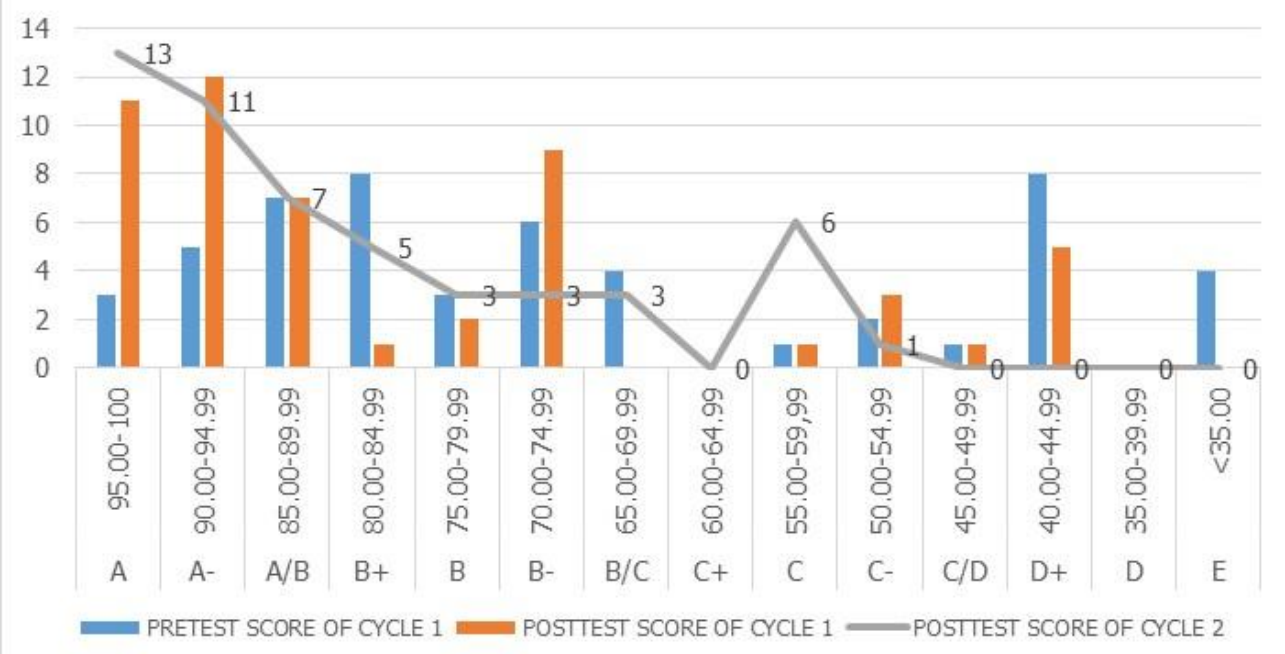

Figure 1. Graphic of Score Improvement for Terjemah Arab-Indonesia Course in Cycle 1 and Cycle 2 
Based on the pretest results of the ability to translate in the pretest of first cycle in Figure 1, the highest score is 100 while the lowest score is 30 with an average score of 68.63 . A total of 3 students $(5.77 \%)$ scored in the range 95.00 100.00 (grade A) and 5 students (9.62\%) scored 90.00-94.99 (grade A-). It means only $8(15.38 \%)$ students scored grade A and A- for Terjemah ArabIndonesia Course. In addition, a total of 15 students scored $<55$. It means $28.85 \%$ students failed to reach minimum standard (grade C) to graduate for Terjemah Arab-Indonesia Course.

From the exposure of graphic in Figure 1 , it is known that the average score obtained by students was in the predicate $B / C$ that has range 65.00-69.99. Based on observations made by researchers, the difficulties experienced by students in translation were influenced by several things, including: (1) a lack of student understanding of grammar, (2) a culture gap or cultural differences that affect the results of translation, (3) selection of diction from inappropriate vocabulary, and (4) lack of interest.

In the first cycle, Jigsaw Cooperative Learning was focused on material about the basics of translation. Students who have been divided into small groups are given a simple text that refers to the theme "Introduction to Translation". This theme consists of four sub-themes, namely the definition of translator, who is the translator, the terms of the translator, and the urgency of the translation. The selection of the theme is intended for students to learn theories about the basics of translation as well as the practice of translating directly.

Translation is a process (Dickins, Hervey, \& Higgins, 2016). Therefore in this study, Students who are in a group have the task of translating the same text. After they were able to translate and understand the text both lexically and contextually, each group member was rolled into a new group consisting of different group members from before. In this new group, each individual had a duty to convey the results of translation and understanding of the text that was previously shared.

The first cycle of Jigsaw Cooperative Learning were conducted for seven meetings with the results of the score as in Figure 1. The highest score obtained by students at the posttest of cycle 1 was 100 and the lowest score was 40, with an average of 77.69 . A total of 11 students (21.15\%) scored in the range $95.00-$ 100.00 (grade A) and 12 students (23.08\%) scored 90.00-94.99 (grade A-). It means 23 (44.23\%) students scored grade A and A- for Terjemah Arab-Indonesia Course. In addition, a total of 9 students scored $<55$. It means $17.31 \%$ students failed to reach minimum standard (grade C) to graduate for Terjemah ArabIndonesia Course.

From the data presented in Figure 1 , it is known that there was an increase in students' ability to translate Arabic texts. It is evidenced by an increase in the 
number of students who get grades in the range of grades 90-100 that reached $44.23 \%$ from 52 students. While the average score obtained by students increased 9.06 points from 68.63 in the pretest cycle 1 to 77.69 in the posttest in cycle 1. From 52 students, there were 9 students failed to reach minimum score 55 to pass Terjemah Arab-Indonesia Course, while there were 1 student got score 55 as it is the minimum score grade C. It means there were $17.31 \%$ students failed to reach minimum score to pass the course.

The results of observations during the first cycle, several facts were found: (1) an increase in students' grammatical understanding, (2) students began to understand different cultures and were able to absorb and translated Arabic texts in appropriate contexts and meanings, (3) selection of diction from vocabulary to be more precise, and (4) increased students' interest and enthusiasm in Arabic translation.

Based on the results obtained in the first cycle, the study continued into the second cycle. The cycle was continued into cycle 2 because the percentage of students' achievement and graduation for Terjemah Arab-Indonesia Course was under $90 \%$ as standard of learning objectives of this course. Jigsaw Cooperative Learning was implemented in cycle 2 by using Arabic literary texts to find out whether Jigsaw Cooperative Learning was effective in improving the quality of student translation in translating various texts. To get more significant results, the second cycle was conducted on the same students.

From the data of posttest in cycle 2 in Figure 1, it is known that $98.08 \%$ students passed Terjemah Arab-Indonesia Course and only $1.92 \%$ or 1 student failed this course. Therefore, the efforts to improve the quality of students' translation was relatively succeed. In the second cycle, the learning material of Arabic text was the poetry anthology of Nizar Qabbani (1970) entitled "Kitab alHubb". Students succeed in translating the poetry anthology using the Jigsaw Cooperative Learning method. This cycle were conducted for seven meetings. After being given treatment in the second cycle, there were an increase in scores obtained by students in the posttest results. There were $13(25.00 \%)$ students scored 95.00-100.00 and got grade A, 11 (21.15\%) students scored 90.00-94.99 and got grade $A-, 7$ students (13.46\%) scored 85.00-89.99 and got grade $A / B, 5$ students (9.62\%) scored $80.00-84.99$ and got grade $B+, 3$ students (5.77\%) scored 75.00-79.99 and got grade B, 3 students (5.77\%) scored 70.00-74.99 and got grade B-, 3 students (5.77\%) scored 65.00-69.99 and got grade B/C, 6 students (11.54\%) scored 55.00-59.99 and got grade $C$ as minimum standard to pass the course, and 1 student (5.77\%) only scored 50.00-54.99 and C- as under standard to pass the course. The highest value obtained at this posttest is 100 , while the lowest value is 50 and the average value of students is 82.67 as presented in Figure 1. 
From the data obtained in the second cycle in Figure 1, it is known that the average score of students increased from 77.69 to 82.67 . The minimum score resulted by students also increased 9.06 points in cycle 1 after being given treatment, as well as an increase 4.98 points from the first cycle to the second cycle. So, hopefully the lowest score obtained by students continue to increase along with the more frequent treatment. Therefore based on the facts and available data, it can be concluded that the use of effective and appropriate Jigsaw Cooperative Learning was used to improve the ethos of learning and the quality of student translation. The research hypothesis which says that Jigsaw Cooperative Learning can improve the ethos of learning and the quality of student translation was proven empirically. This learning process also crucially depends on the quality of the interaction between students in Jigsaw Cooperative Learning (Berger \& Hänze, 2015) and students get new knowledge and vocabularies to use in the upcoming situations (Khoshsima \& Saed, 2016).

The results of this study indicated that Jigsaw Cooperative Learning demands active student involvement. It is also effectively used in translation learning. It is in line with Confucius learning theory which says that "what I hear, I forget; what I see I remember and what I do, I understand" (Munthe, 2016) so that the most appropriate learning method or strategy is a method or strategy that involves student activity or known as student-centered learning.

Other theories that supports student-centered learning is Edgar Dale's cone of experience. According to Dale, a person will quickly absorb learning material using active learning methods compared to passive learning. Jigsaw Cooperative Learning is one of cooperative learning that has four components, they are: posistive and social interdependence (Baloche \& Brody, 2017), collaborative skills, processing group interaction and focused exploration (Karacop \& Doymus, 2013), and individual accountability (Yuliasri, 2014). Jigsaw Cooperative Learning that was counducted in this study has completed these four components. Therefore, Jigsaw Cooperative Learning helpfully improve students' competence in Arabic translation skill.

\section{CONCLUSIONS}

Jigsaw Cooperative Learning improved students competence in Arabic translation. Jigsaw Cooperative Learning impacted to students' learning independence. It was indicated from students' ability to set a learning agenda and lessons, a belief in self abilities, and completing the tasks and responsibilities without depending on others. These indicators can be classified into learning ethos. This learning ethos develops students' learning indpendence because through Jigsaw Cooperative Learning, students actively seek knowledge and 
vocabulary from reading, listening, and viewing according to their tasks and responsibilities because learning process will be easy when students actively seek knowledge themselves. After seeking knowledge, students must share knowledge they get to the small group then to all students in front of class. Jigsaw Cooperative Learning process set up heterogeneous groups that contained 5-6 students. Each student in the group was given a different sub topic and each group read and discussed their respective sub topics and assigned expert members who joined the expert group. The learning results of students were also increased as it is known from the increasing of Terjemah Arab-Indo course's score. This research results shows that Jigsaw Cooperative Learning can helpfully improve students' competence in translation. This study has limitation. The future study can be done with the evaluation of learning outcomes of translation course through more complex tests and assesment.

\section{ACKNOWLEDGMENT}

We thank all the people who helped us to write the article. We also thank to UIN Sunan Kalijaga Yogyakarta for the good academic atmosphere until we can learn how to conduct research and write this small thing. We present this article to Arabic language lovers, Arabic language students, and all people who have given their best to teach this lovely language. Our thanks are also to people who helped intensely in the research and writing of the article.

\section{BIBLIOGRAPHY}

Ariyanti, M. L., \& Tanjung, S. (2019). Hubungan Kompetensi Penerjemah dan Kualitas Terjemahan. Jurnal IImiah Bina Bahasa, 12(1), 21-30. DOI: https://doi.org/10.33557/binabahasa.v12i1.206

Asrori, I. (2016). Mengadopsi Teori Medan Makna Menjadi Metode Pengajaran Bahasa Arab di Era Posmetode. Prosiding Konfererensi Nasional Bahasa Arab, 1(2). http://prosiding.arabum.com/index.php/konasbara/article/view/44/0

Baharudin, H. (2017). Strategi dan Teknik Terjemahan Novel Arab dalam Kalangan Pelajar Universiti (Arabic Novel Translation Strategies and Techniques used among University Students). GEMA Online $\mathbb{R}$ Journal of Language Studies, 174), 225-243. DOI:

http://dx.doi.org/10.17576/gema-2017-1704-15 
Baloche, L., \& Brody, C. M. (2017). Cooperative Learning: Exploring Challenges, Crafting Innovations. 43(3), 274-283. DOI: https://doi.org/10.1080/02607476.2017.1319513

Barr, C. D., Uccelli, P., \& Galloway, E. P. (2019). Specifying the Academic Language Skills that Support Text Understanding in The Middle Grades: The Design and Validation of the Core Academic Language Skills Construct and Instrument. Language Learning, 69(4), 978-1021. DOI: https://doi.org/10.1111/lang.12365

Berger, R., \& Hänze, M. (2015). Impact of expert teaching quality on novice academic performance in the jigsaw cooperative learning method. International Journal of Science Education, 372), 294-320. DOI: https://doi.org/10.1080/09500693.2014.985757

Caplan, N. A. (2019). Learning through Language: A Response to Polio,"Keeping the Language in Second Language Classes." Journal of Second Language Writing, 46, 100676-100677. DOI: https://doi.org/10.1016/j.jslw.2019.100677

Dickins, J., Hervey, S., \& Higgins, I. (2016). Thinking Arabic Translation: A Course in Translation Method: Arabic to English. Taylor \& Francis.

Fahrurrozi, A. (2014). Pembelajaran Bahasa Arab: Problematika dan Solusinya. Arabiyat: Jurnal Pendidikan Bahasa Arab Dan Kebahasaaraban, 1(2), 161-180. DOI: https://doi.org/10.15408/a.v1i2.1137

Fauzi, M. F., Buhun, M. F., \& Purwadi, A. (2019). The Influence of Teams Games Tournament (TGT) toward Students' Interest in Arabic Language Learning. Izdihar: Journal of Arabic Language Teaching, Linguistics, and Literature, 2(2), 135-148. DOI: https://doi.org/10.22219/jiz.v2i2.9986

Feng, Y., \& Webb, S. (2019). Learning Vocabulary Through Reading, Listening, and Viewing: Which Mode of Input is Most Effective? Studies in Second Language Acquisition, 1-25. DOI: https://doi.org/10.1017/S0272263119000494

Habibullah, M. (2015). Proses dan Hasil Penerjemahan Mahasiswa (Studi Kasus Pada Mahasiswa Translation Theory and Practice Di STAIN Pamekasan). NUANSA: Jurnal Penelitian IImu Sosial dan Keagamaan Islam, 12(1), 207-232. DOI: http://dx.doi.org/10.19105/nuansa.v12i1.703 
Harahap, K. A. (2014). Analisis Kesalahan Linguistik Hasil Terjemahan Mesin

Terjemah Google Translate dari Teks Bahasa Arab ke dalam Bahasa Indonesia. Jurnal Penelitian Agama, 15(1), 26-43. DOI:

https://doi.org/10.24090/JPA.V15I1.2014.PP26-43

Hidayatullah, M. S. (2017). Jembatan Kata: Seluk Beluk Penerjemahan ArabIndonesia. Jakarta: Gramedia Widiasarana.

Karacop, A., \& Diken, E. H. (2017). The Effects of Jigsaw Technique Based on Cooperative Learning on Prospective Science Teachers' Science Process Skill. Journal of Education and Practice, 8(6), 86-97. Call Number: EJ1133003

Karacop, A., \& Doymus, K. (2013). Effects of jigsaw cooperative learning and animation techniques on students' understanding of chemical bonding and their conceptions of the particulate nature of matter. Journal of Science Education and Technology, 22(2), 186-203. DOI: https://doi.org/10.1007/s10956-012-9385-9

Kemmis, S., McTaggart, R., \& Nixon, R. (2014). Introducing Critical Participatory Action Research. Dalam The Action Research Planner (pp. 1-31). Springer.

Khoshsima, H., \& Saed, A. (2016). Task-Based Instruction and Vocabulary Learning: A Comparative Study of Jigsaw and Information Gap Tasks on Vocabulary Learning. International Journal of Applied Linguistics and English Literature, 5(5), 228-236. DOI: http://dx.doi.org/10.7575/aiac.ijalel.v.5n.5p.228

Mahbubah, L., Biahmada, A. M. M., \& Mauludiyah, L. (2020). Learning Arabic Translation at Islamic Boarding School in Madura. Izdihar: Journal of Arabic Language Teaching, Linguistics, and Literature, 2(3), 231-242. DOI: https://doi.org/10.22219/jiz.v2i3.10578

Miles, Huberman, A. M., \& Saldana, J. (2014). Qualitative Data Analysis: Methodes Sourcebook (Third Edit). Singapore: Sage.

Munthe, B. (2016). Strategi Mengajar Aktif, Kreatif, Inovatif(Second Edition). Yogyakarta: mSuka Press. 
Nikmah, K. (2019). Meaning Variations of Qāla (قال) in Indonesian Language. Izdihar: Journal of Arabic Language Teaching, Linguistics, and Literature, 2(2), 77-100. DOI: https://doi.org/10.15408/bat.v25i1.11506

Nurbayan, Y. (2014). Pengaruh Struktur Bahasa Arab terhadap Bahasa Indonesia dalam Terjemahan Al-Qur'an. Arabiyat: Jurnal Pendidikan Bahasa Arab dan Kebahasaaraban, 1(1), 21-28. DOI: https://doi.org/10.15408/a.v1i1.1128

Pellicer-Sánchez, A. (2016). Incidental L2 Vocabulary Acquisition from and while Reading: An Eye-Tracking Study. Studies in Second Language Acquisition, 38(1), 97-130. DOI: https://doi.org/10.1017/S0272263115000224

Perdana, D. H. (2017). Strategi Penerjemahan Bahasa Arab yang Berterima dan Mudah Dipahami. Jurnal Bahasa Lingua Scientia, 9(1), 143-160. DOI: https://doi.org/10.21274/Is.2017.9.1.143-160

Qabbani, N. (1970). Kitab al-Hubb. Cairo: Mansyurat Nizar Qabbani.

Sari, R. R. (2018). The Use of Keyword and Imagery Mnemonic for Vocabularies Learning for AFL Students. Izdihar: Journal of Arabic Language Teaching, Linguistics, and Literature, 1(2), 129-136. DOI: https://doi.org/10.22219/izdihar.v1i2.7294

Somadayo, S. (2013). Penelitian Tindakan Kelas. Yogyakarta: Graha Ilmu.

Wahyono, S. B., Hardianto, D., \& Miyarso, E. (2014). Pengukuran Indeks Etos Belajar Siswa di Daerah Istimewa Yogyakarta. Jurnal Kependidikan: Penelitian Inovasi Pembelajaran, 44(1), 51-63. DOI: https://doi.org/10.21831/jk.v44i1.2191

Wicaksono, A., \& Roza, A. S. (2015). Teori Pembelajaran Bahasa: Suatu Catatan Singkat. Yogyakarta: Penerbit Garudhawaca.

Yamada, M., Goda, Y., Hata, K., Matsukawa, H., \& Yasunami, S. (2016). Flip-J: Development of the System for Flipped Jigsaw Supported Language Learning. Research-publishing. net, 490-495. DOI: https://doi.org/10.14705/rpnet.2016.eurocall2016.612

Yuliasri, I. (2014). Cooperative Learning Techniques to Improve Students' Translation. Language Circle: Journal of Language and Literature, 8(2), 107-114. DOI: https://doi.org/10.15294/lc.v8i2.3015 